\title{
Reynolds Number Estimation Of Rotameter BASED ON $K$-EPSILON MODEL
}

\section{ESTIMASI BILANGAN REYNolds PADA Rotameter MENGGUNakAN Model K-EPSILON}

\begin{abstract}
Bahrudin ${ }^{1, *}$ and Hilman Syaeful Alam ${ }^{1}$
${ }^{1}$ Technical Implementation Unit for Instrumentation Development, Indonesian Institute of Sciences Jl. Sangkuriang Komplek Lembaga Ilmu Pengetahuan Indonesia, Gedung 30 Bandung, 40135, Indonesia. *E-mail: bahr003@lipi.go.id
\end{abstract}

\begin{tabular}{|c|c|}
\hline ART I C LE I NFO & Abstrak \\
\hline $\begin{array}{l}\text { Article history } \\
\text { Received date: } \\
5 \text { April } 2016 \\
\text { Received in revised form date: } \\
18 \text { October } 2016 \\
\text { Accepted date: } \\
19 \text { October } 2016 \\
\text { Available online date: } \\
31 \text { May } 2017\end{array}$ & $\begin{array}{l}\text { Pengukuran aliran fluida dengan memanfaatkan elemen apung } \\
\text { (rotameter) adalah metode sederhana yang digunakan untuk meng- } \\
\text { ukur kecepatan cairan dengan tingkat akurasi yang lebih baik. Akan } \\
\text { tetapi, masih ada kecenderungan terjadi turbulensi di sekitar elemen } \\
\text { apung (area annular), karena penyempitan daerah aliran dan bentuk } \\
\text { geometri elemen apung yang dapat mengurangi tingkat akurasi } \\
\text { rotameter. Aliran berfase tunggal yang melalui rotameter telah di- } \\
\text { simulasikan dengan menggunakan model turbulensi k-epsilon. Studi } \\
\text { secara detail telah dilakukan untuk menyelidiki pengaruh karakter- } \\
\text { istik turbulensi dari Reynolds Number (Re) sebagai patokan untuk } \\
\text { memprediksi tingkat turbulensi. Hasil penelitian menunjukan bahwa } \\
\text { pada kecepatan } 800 \text { l/h level bilangan Re adalah sekitar } 450 \text { yang } \\
\text { mengindikasikan aliran fluida pada rotameter dapat dikategorikan } \\
\text { sebagai aliran turbulen. }\end{array}$ \\
\hline
\end{tabular}

Kata kunci: Rotameter, Kecepatan alir, K-epsilon, Bilangan reynolds

Keywords:

Rotameter

Velocity

$K$-epsilon

Reynolds number

\begin{abstract}
Measurement of fluid flow with the aid of a floating element (rotameter) is a simple method used to measure the velocity of the fluid with a better degree of accuracy. However, there is still a tendency for turbulence flows around the floating element (annular area) due to narrowing of the flows area and the geometry shape of the floating element that can reduce the level of the rotameter accuracy. A single phase of turbulent flows through rotameter was estimated using $k$-epsilon turbulence model. A detailed study has been performed to investigate the influence of turbulence characteristics from the Reynolds Number $(R e)$ as a benchmark for predicting the level of turbulence. The results showed that at the velocity of $800 \mathrm{l} / \mathrm{h}$ the level is around 450, which showed that the fluid flow on the rotameter is categorized as turbulence.
\end{abstract}




\section{INTRODUCTION}

Flow meter has been widely used for the measurement flow rate in the industrial control process of fluid flow either liquid or gas fluid. One of the most widely used is the rotameter, which uses the principle of a float or floating element as a flow indicator. Rotameter composes of a vertical transparent tube with a tapered tube-shaped hole with a float inside maintained by the steering shaft. The movement of the float will occur if the fluid flow enters from the bottom of the hole to against the gravity and push a float upward as thrust. However the float will be pulled down by the gravity so that the equilibrium change to among thrust, gravity, buoyancy, and drag was obtained so that the reading stability will be provided. Fluid flow on the rotameter can be measured by looking at the level of the float on a transparent tube (Joshi, Jolly, and Singh 2013; P, Seshadri, and B 2015).

Computational Fluid Dynamic (CFD) is a numerical analysis method that can be used for fluid flow, heat transfer, and chemical reactions analysis by means of computer-based simulation (Mala 2007;Deng et al. 2012; Joshi, Jolly, and Singh 2013; Ángel et al. 2013; Hosain and Fdhila 2015). The CFD shows the detail of flow characteristics such as velocity, pressure distribution, flow vector, and Reynolds number (Re) (Hanada, Kuroda, and Takahashi 2016). For turbulent flow, the standard of $\mathrm{k}$-epsilon (k- $\varepsilon$ ) model has been widely used to analyze turbulence model for the solution of practical engineering flow problems (Lostedt and Carlbom 1997; Li and Zhu 2002; Rolander et al. 2006; Ahsan 2014).

In early research, rotameter has beenstudied using experimental and numerical simulation. It was carried out using a two-dimensional finite volume, multigrid computational program. The experimentaldata shows $R e$ about 400 at
$25 \mathrm{~cm} / \mathrm{s} 10$ and the numerical result shows velocity profile through rotameter (Bockle et al.1992). Another method is using FLUENT to characterize the flow, and the result showed that flow on rotameter is laminar (Alam 2008). In 2013, Joshi and his college studied the flow on rotameter using FLUENT to analyze velocity, pressure and streamline profile (Joshi, Jolly, and Singh 2013). Another method is using FLUENT to compare velocity data between experimental and numerical method (P, Seshadri, and B 2015). However, all of the numerical methods of the aforementioned papers are not fully 3-dimensional geometry and using FLUENT simulation software. Therefore, the main objective of this research is to analyze the characteristic of flow using ANSYS CFX to shows Reynolds number on rotameter with $\mathrm{k}-\varepsilon$ turbulence model at 3-dimensional geometry.

\section{METHODOLOGY}

The experimental data are analyzed to determine the characteristics of the velocity based on a phenomenon that occurs as described below. Reaction motion on balance between the float element mass is $\rho_{b} g V_{b}$ with $\rho_{g} g V_{b}$ buoyancy and drag force is $F_{d}$, where $\rho_{b}$ and $V_{b}$ are the density and volume of float, respectively and $\rho$ is the density of the fluid. The phenomenon was explained in Eq. (1) (Bockle et al. 1992):

$$
\rho_{b} g V_{b}=\rho_{g} g V_{b}+F_{d},
$$

Floating element moves up due to the drag force obtained from the average velocity profile of fluid flow that surrounds the float. In this case, drag force can be calculated by taking the effect of laminar and turbulent flows. The effect is calculated with empirical coefficient $\mathrm{C}_{\mathrm{T}}$ on drag force for turbulence flow (Bockle et al. 1992): 
$F_{d}=C_{T} \rho D_{b}^{2} U^{2}$

where $\rho$ is fluid density, $D_{b}$ is maximum diameter of the float and $U$ is fluid velocity at the smallest distance difference annular region around the float. Fluid flow rate through the rotameter is (Bockle et al. 1992):

$Q=\frac{\pi}{4}\left(D^{2}-D_{b}^{2}\right) U$

where $D$ is the diameter of the tube at the top of the floating element. Figures $R e$ on through rotameter can be calculated using Eq. (4):

$R e=\frac{\rho U_{I N} D_{b}}{\mu}$,

where $U_{I N}$ is velocity inlet. The equation of turbulent flow can be determined as follows:

$Q_{T}=\beta D_{b}^{5 / 2} \sqrt{\frac{\left(\rho_{b}-\rho\right) g}{\rho}}$,

where:

$\beta=\frac{\pi m}{4} \sqrt{\frac{K}{c_{T}}}$

In the mathematical modeling of the flow, conservation equations for mass and momentum in cylindrical coordinate the system can be explained as follows (Kulkarni, Sahoo, and Chavan 2011; Hosain and Fdhila 2015)

$$
\frac{\partial \rho}{\partial t}+\frac{1}{r} \frac{\partial}{\partial r}\left(\rho r u_{r}\right)+\frac{1}{r} \frac{\partial\left(\rho u_{\emptyset}\right)}{\partial \emptyset} \frac{\partial\left(\rho v_{z}\right)}{\partial z},
$$

$$
\begin{aligned}
& r: \rho\left(\frac{\partial u_{r}}{\partial t}+u_{r} \frac{\partial u_{r}}{\partial r}+\frac{u_{\emptyset}}{r} \frac{\partial u_{r}}{\partial \emptyset}+u_{z} \frac{\partial u_{r}}{\partial z}-\frac{u_{\emptyset}^{2}}{r}\right) \\
& =-\frac{\partial p}{\partial t}+\mu\left[\frac{1}{r} \frac{\partial}{\partial r}\left(r \frac{\partial u_{r}}{\partial_{r}}\right)+\frac{1}{r^{2}} \frac{\partial^{2} u_{r}}{\partial \emptyset^{2}}+\frac{\partial^{2} u_{r}}{\partial z^{r}}-\frac{u_{r}}{r^{2}}-\frac{2}{r^{2}} \frac{\partial u_{\emptyset}}{\partial \emptyset}\right]+\rho g_{r},
\end{aligned}
$$

$$
\begin{aligned}
& \emptyset: \rho\left(\frac{\partial u_{\emptyset}}{\partial t}+u_{r} \frac{\partial u_{\emptyset}}{\partial r}+\frac{u_{\emptyset}}{r} \frac{\partial u_{\emptyset}}{\partial \emptyset}+u_{z} \frac{\partial u_{\emptyset}}{\partial z}+\frac{u_{r} u_{\emptyset}}{r}\right. \\
& =-\frac{1}{r} \frac{\partial p}{\partial \emptyset}+\mu\left[\frac{1}{r} \frac{\partial}{\partial r}\left(r \frac{\partial u_{\emptyset}}{\partial_{r}}\right)+\frac{1}{r^{2}} \frac{\partial^{2} u_{\emptyset}}{\partial \emptyset^{2}}+\frac{\partial^{2} u_{\emptyset}}{\partial z^{2}}+\frac{2}{r^{2}} \frac{\partial u_{r}}{\partial \emptyset}-\frac{u_{\emptyset}}{r^{2}}\right]+\rho g_{\emptyset},
\end{aligned}
$$

$$
\begin{aligned}
& z: \rho\left(\frac{\partial u_{z}}{\partial t}+u_{r} \frac{\partial u_{z}}{\partial r}+\frac{u_{\emptyset}}{r} \frac{\partial u_{z}}{\partial r}+u_{z} \frac{\partial u_{z}}{\partial z}\right) \\
& =-\frac{\partial p}{\partial z}+\mu\left[\frac{1}{r}\left(r \frac{\partial}{\partial_{r}}\right)+\frac{1}{r^{2}} \frac{\partial^{2} u_{z}}{\partial \emptyset^{2}}+\frac{\partial^{2} u_{z}}{\partial z^{2}}\right]+\rho g_{z},
\end{aligned}
$$

where $\rho$ is the density, $\mu$ is component speeds, while $r, \Phi$, and $z$ are cylindrical coordinate parameters. $\mu$ is the dynamic viscosity, and $P$ is the pressure.

It is important to perform accurate measurements of the $R e$ as a parameter flow in the CFD as a benchmark for predicting the level of turbulence. CFD numerical methods do not provide the parameters $R e$ variable output. Hence, Re for CFD method can be searched analytically by Eq. (11) (Husein, Abdullah, and Alimuddin 2008; ANSYS(1) 2013; ANSYS(2) 2013)

$$
R e_{c f d}=\frac{\rho u d^{3}}{\mu},
$$

where $R e_{c f d}$ is Reynolds Number on CFD model, $\rho$ is the density of a fluid, $u$ is velocity magnitude, $d$ is cell volume, and $\mu$ is effective viscosity. Details of flow pattern is depends on the Re. Figure 1 shows a principal description of the various occurring flow phenomena. 


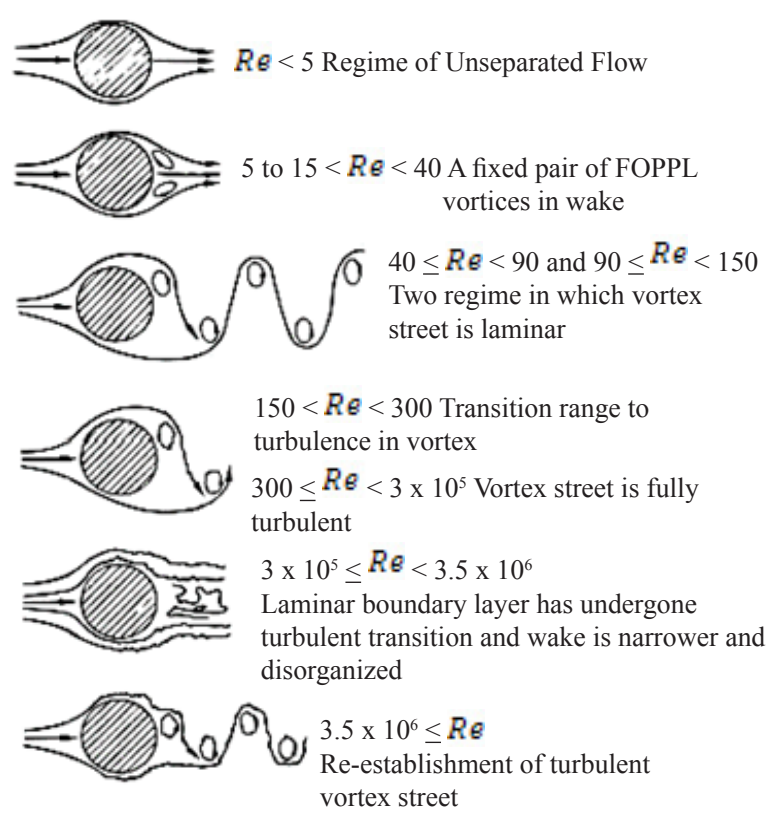

Figure 1. Fluids flow regimes Source (Blevins 2001)

This study collaborates theoretical analysis and the numerical simulations. The working fluid through rotameter was water with properties of fluid as follows: density is $997 \mathrm{~kg} / \mathrm{m}^{3}$, buoyancy is $9.8 \mathrm{~m} / \mathrm{s}^{2}$ at reference temperature $25^{\circ} \mathrm{C}$, viscosity $\mu$ is $0.001003 \mathrm{~kg} / \mathrm{m}^{3}$. Since the rotameter has a capacity up to $1000 \mathrm{l} / \mathrm{h}$, then this study used four flow rate variables which were 200 l/h; 400 l/h; 600 l/h; and 800 l/h. Measurement point can be seen in Figure 2. The Float of rotameter was made of stainless steel with density is $\rho_{b}=7900 \mathrm{~kg} / \mathrm{m}^{3}$, volume $V_{b}=2.8685 \times 10^{-6} \mathrm{~m}^{3}$, and the maximum diameter is $D_{b}=0.018 \mathrm{~m}$. Inlet diameter of rotameter is $D_{I N}=0.01875 \mathrm{~m}$ and outlet diameter is $D_{\text {OUT }}=0.02520 \mathrm{~m}$.

The geometry of rotameter is created using ANSYS geometry modeling. On the numerical simulation, rotameter modeling domain has been divided into two parts, namely solid and fluid domains. Solid domain comprises the outer wall, float, and steering. In the fluid, domain fluid is defined as water in accordance to the fluid

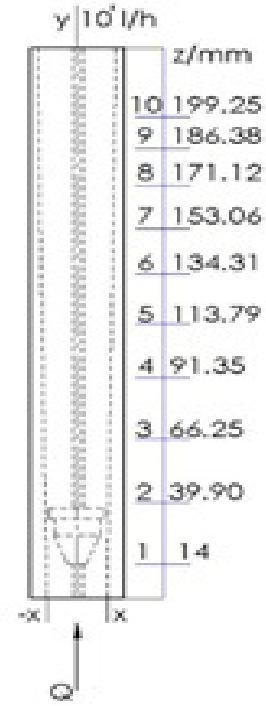

Figure 2. Results of float position experimental measurements

Source (Alam 2008)

which was used in the experiment and numerical simulation.

Meshing divides the structure into smaller elements which are connected by the nodes. The element of meshing used physic preference on FCD, and the solver preference using CFX-method. The element of CFX method was fine tetrahedral meshing. The sample of meshing at 200 $1 / \mathrm{h}$ can be seen in Figure 3. The sample of meshing at $200 \mathrm{l} / \mathrm{h}$ can be seen in Figure 3 . The flow rate at $200 \mathrm{l} / \mathrm{h}$ obtained mesh-

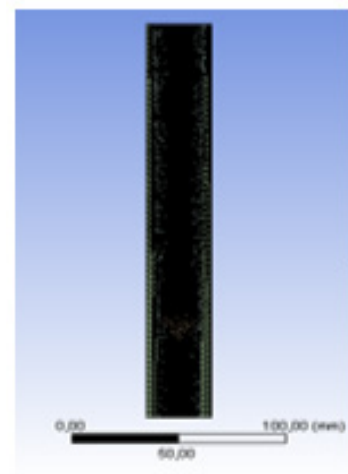

(a)

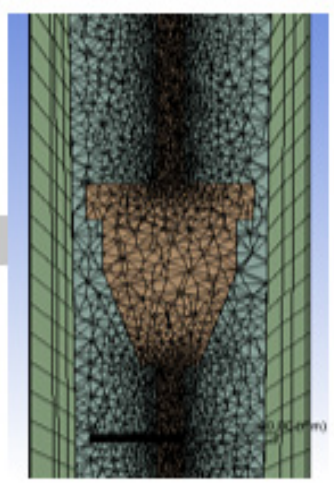

(b)
Figure 3. Meshing of a rotameter at flow rate 200 $\mathrm{l} / \mathrm{h}$ (a) zoom out (b) zoom in 
ing with the number of 98887 nodes and 499311 elements.

To perform a numerical analysis using CFX, the boundary condition has to be determined by the geometry of rotameter such as a parameters of the inlet, outlet, wall, fluid domain, wall, and numerical method. Fluid models on CFX used isothermal heat transfers, while for turbulence modeling used $k-\varepsilon$ model.

Figure 4 shows boundary conditions on the inlets of rotameter using parameter "Inlet" with varied flow parameter using the flow rate $(\mathrm{Q} 1 / \mathrm{h})$ in the variation of 200 l/h; $400 \mathrm{l} / \mathrm{h} ; 600 \mathrm{l} / \mathrm{h}$; and $800 \mathrm{l} / \mathrm{h}$. The outlet section used the parameter "Output" with

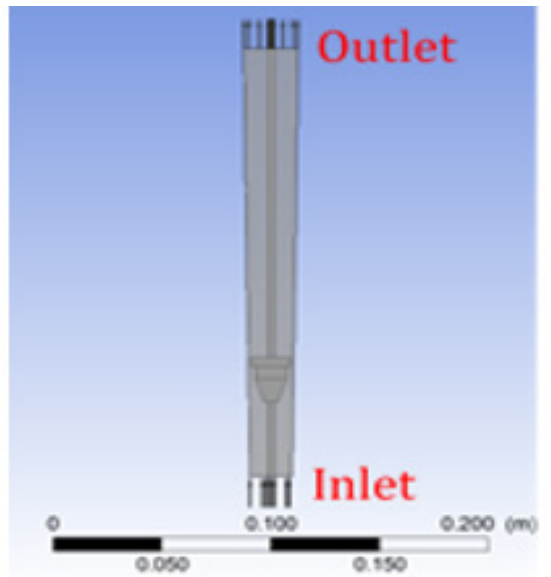

Figure 4. Boundary condition at $200 \mathrm{l} / \mathrm{h}$ flow rate the same parameters as the parameters Inlet without determination of turbulence option. Scalable wall functions were used on the surface side of the domain wall as a solid, which applies to each meshing model different. With the boundary conditions are placed on the model of a solid wall, float element, and float steering.

\section{RESULT AND DISCUSSION}

\section{Theoretical Analysis}

Theoretical result as shown in Table 1 has been obtained from calculating the experimental data using Eqs. 1 to 4. It was concluded that the velocity $U$ along the float was linear with flow rate on the inlet $U_{\text {in }}$ and outlet Uout. However, the theoretical data above are not able to provide a clear picture of the flow characteristic that occur on the rotameter like the contours of the velocity vector and the turbulence model as a three-dimensional model of the $\mathrm{x}, \mathrm{y}$, and $\mathrm{z}$ vectors.

\section{Analysis of simulation}

The main objective of this study is to characterize the fluid flow using Reynolds

Table 1. Theoretically data analysis

\begin{tabular}{cccccccccccc}
\hline & $\mathrm{Q}$ & $\mathrm{D}$ & $\mathrm{Db}$ & $\mu$ & $\mathrm{P}$ & $\mathrm{Vb}$ & $\mathrm{Fd}$ & $\mathrm{UIN}$ & $\mathrm{UOUT}$ \\
Point & $\mathrm{l} / \mathrm{h}$ & $\mathrm{m}$ & $\mathrm{M}$ & $\mathrm{kg} / \mathrm{m}-\mathrm{s}$ & $\mathrm{kg} / \mathrm{m} 3$ & $\mathrm{~m} 3$ & $\mathrm{~N}$ & $\mathrm{~m} / \mathrm{s}$ & $\mathrm{m} / \mathrm{s}$ & $\mathrm{m} / \mathrm{s}$ \\
\hline 1 & 100 & 0.01915 & 0.01800 & $1.00 \mathrm{E}-03$ & 998.2 & $2.87 \mathrm{E}-06$ & $1.94 \mathrm{E}-01$ & $1.01 \mathrm{E}-01$ & $5.57 \mathrm{E}-02$ & $8.28 \mathrm{E}-01$ \\
2 & 200 & 0.01988 & 0.01800 & $1.00 \mathrm{E}-03$ & 998.2 & $2.87 \mathrm{E}-06$ & $1.94 \mathrm{E}-01$ & $2.01 \mathrm{E}-01$ & $1.11 \mathrm{E}-01$ & $9.93 \mathrm{E}-01$ \\
3 & 300 & 0.02063 & 0.01800 & $1.00 \mathrm{E}-03$ & 998.2 & $2.87 \mathrm{E}-06$ & $1.94 \mathrm{E}-01$ & $3.02 \mathrm{E}-01$ & $1.67 \mathrm{E}-01$ & $1.04 \mathrm{E}+00$ \\
4 & 400 & 0.02134 & 0.01800 & $1.00 \mathrm{E}-03$ & 998.2 & $2.87 \mathrm{E}-06$ & $1.94 \mathrm{E}-01$ & $4.02 \mathrm{E}-01$ & $2.23 \mathrm{E}-01$ & $1.08 \mathrm{E}+00$ \\
5 & 500 & 0.02197 & 0.01800 & $1.00 \mathrm{E}-03$ & 998.2 & $2.87 \mathrm{E}-06$ & $1.94 \mathrm{E}-01$ & $5.03 \mathrm{E}-01$ & $2.78 \mathrm{E}-01$ & $1.11 \mathrm{E}+00$ \\
6 & 600 & 0.02255 & 0.01800 & $1.00 \mathrm{E}-03$ & 998.2 & $2.87 \mathrm{E}-06$ & $1.94 \mathrm{E}-01$ & $6.03 \mathrm{E}-01$ & $3.34 \mathrm{E}-01$ & $1.15 \mathrm{E}+00$ \\
7 & 700 & 0.02308 & 0.01800 & $1.00 \mathrm{E}-03$ & 998.2 & $2.87 \mathrm{E}-06$ & $1.94 \mathrm{E}-01$ & $7.04 \mathrm{E}-01$ & $3.90 \mathrm{E}-01$ & $1.19 \mathrm{E}+00$ \\
8 & 800 & 0.02302 & 0.01800 & $1.00 \mathrm{E}-03$ & 998.2 & $2.87 \mathrm{E}-06$ & $1.94 \mathrm{E}-01$ & $8.04 \mathrm{E}-01$ & $4.45 \mathrm{E}-01$ & $1.37 \mathrm{E}+00$ \\
9 & 900 & 0.02402 & 0.01800 & $1.00 \mathrm{E}-03$ & 998.2 & $2.87 \mathrm{E}-06$ & $1.94 \mathrm{E}-01$ & $9.05 \mathrm{E}-01$ & $5.01 \mathrm{E}-01$ & $1.26 \mathrm{E}+00$ \\
10 & 1000 & 0.02439 & 0.01800 & $1.00 \mathrm{E}-03$ & 998.2 & $2.87 \mathrm{E}-06$ & $1.94 \mathrm{E}-01$ & $1.01 \mathrm{E}+00$ & $5.57 \mathrm{E}-01$ & $1.31 \mathrm{E}+00$ \\
\hline
\end{tabular}


number on single-phase turbulent flow in the rotameter through numerical simulation. The results of the streamlines velocity profile, velocity fluctuation, and separation reattachment points for different Reynolds numbers along the various positions in a three-dimensional model are presented in this section.

The results of CFD simulation using $k-\varepsilon$ simulation model conducted by the

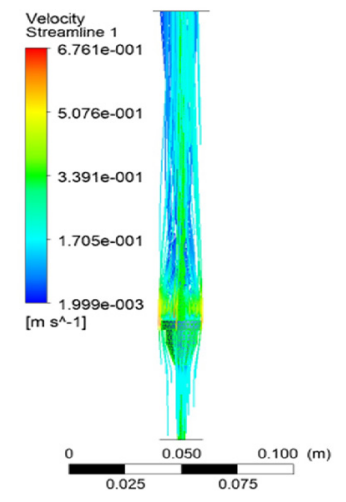

(a)

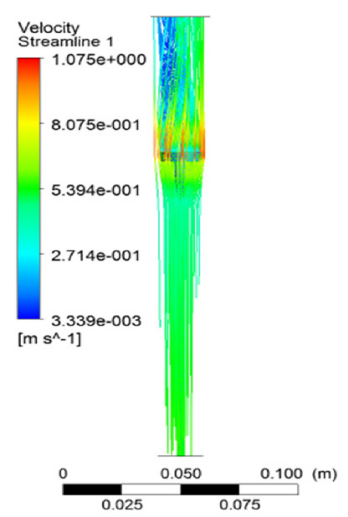

(c)

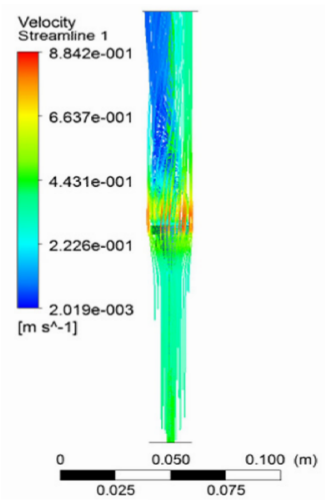

(b)

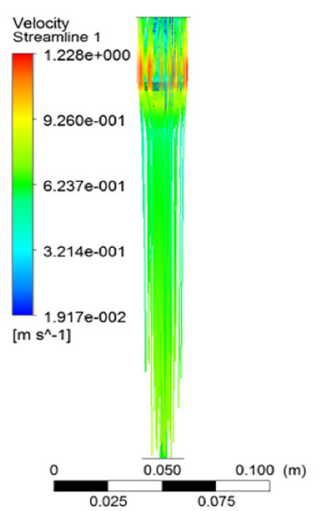

(d)
Figure 5. Streamline flow in each variation of flow measurement at (a) $200 \mathrm{l} / \mathrm{h}$; (b) $400 \mathrm{l} / \mathrm{h}$; (c) $600 \mathrm{l} / \mathrm{h}$; (d) $800 \mathrm{l} / \mathrm{h}$

method of finite volume are shown in Figure 5. In detail, the characteristic of the flow can be visualized more accurately with 3D streamlines which depicts the nature of the fluid flow. Figure 5 shows velocity contours after float element was not stable and it was characterized by vortex around the annular area. The vortex can be reduced by modifying the sudden construction of the floating geometry.

The fluctuation of velocity does not imply the flow turbulence, because from six type of fluid flow regimes, only three showed vortex characteristic of turbulence. Details analysis of turbulence phenomenon has been provided in the Figure 6-9. Figure 6 shows flow characteristic of rotameter at $2001 / \mathrm{h}$ where Figure 6 (a) shows the velocity characteristic of fluid flow through rotameter at $200 \mathrm{l} / \mathrm{h}$. The modeling results show maximum velocity due to the contour geometry was $0.48 \mathrm{~m} / \mathrm{s}$. Figure 6 (b) shows at the midplane of the rotameter, around

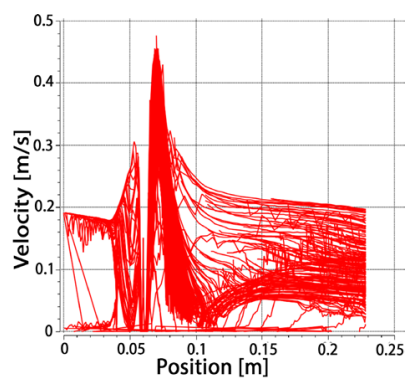

(a)

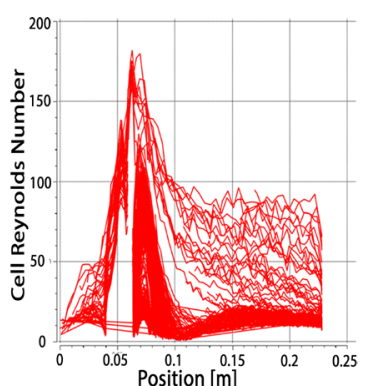

(b)
Figure 6. The relationship between fluid velocity and Reynolds numbers at 200 1/h (a) velocity (b) Reynolds number

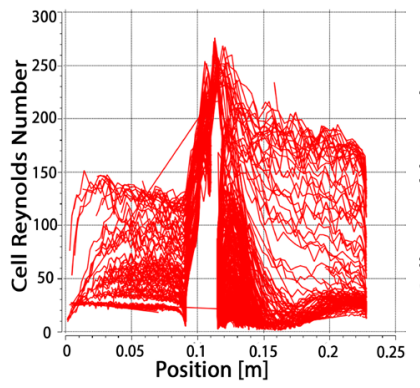

(a)

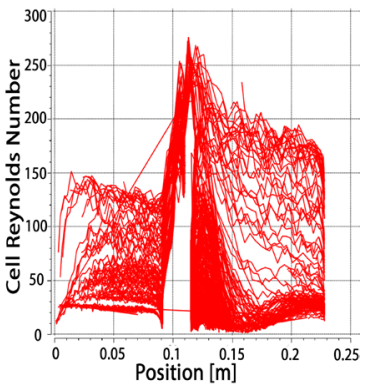

(b)
Figure 7. Relationship between fluid velocity and Reynolds numbers at $400 \mathrm{l} / \mathrm{h}$ (a) velocity (b) Reynolds number

the steering float, has a maximum $R e=180$ spread evenly across the region of sudden contraction. It means that the characteristic of fluid flow at $200 \mathrm{l} / \mathrm{h}$ run into regimes of transitions turbulence in the vortex.

Figure 7 (a) shows the characteristic of velocity at $400 \mathrm{l} / \mathrm{h}$ attain maximum 
speed around floating element is $0.79 \mathrm{~m} / \mathrm{s}$. The velocity variations also increased from $200 \mathrm{l} / \mathrm{h}$ to $400 \mathrm{l} / \mathrm{h}$, while the flow properties based on Reynolds number attain at $R e=$ 280 . It can be ascertained that flow rate at $400 \mathrm{l} / \mathrm{h}$ still run into transitions turbulence in a vortex.

Figure 8 shows the characteristic of velocity at $400 \mathrm{l} / \mathrm{h}$. The maximum velocity around floating element attains at 0.89 $\mathrm{m} / \mathrm{s}$. The increased speed is affected by a higher rising float, which means that the gap between the walls of the float rotameter increases widely and provides more space for fluid to run in regions around floating element. The maximum of Reynolds number at $600 \mathrm{l} / \mathrm{h}$ is $R e=410$, which means that the characteristic of the flow at $600 \mathrm{l} / \mathrm{h}$ is starting to transform to regimes

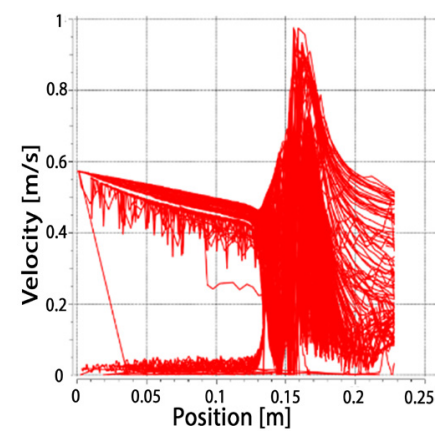

(a)

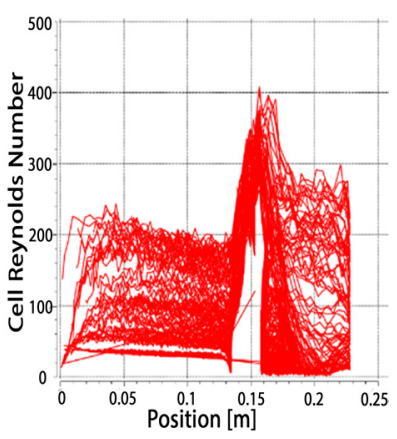

(b)
Figure 8. The relationship between fluid velocity and Reynolds numbers at 600 1/h (a) velocity (b) Reynolds number

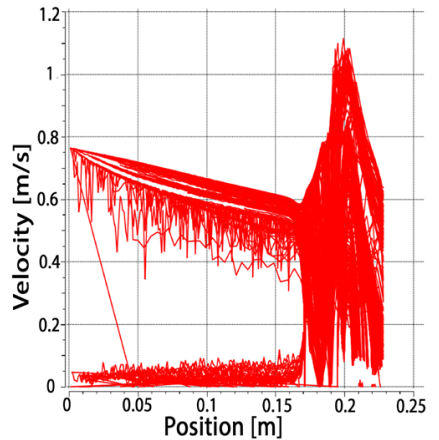

(a)

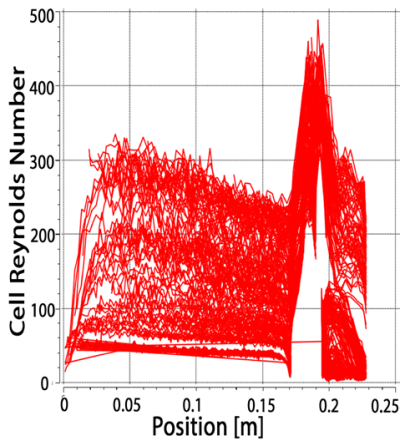

(b)
Figure 9. Relationship between fluid velocity and Reynolds numbers at $800 \mathrm{l} / \mathrm{h}$ (a) velocity (b) Reynolds number of vortex-street is fully turbulent. There is a possibility that the fluctuation of velocity reacts to floating element and it causes the floating element to vibrate and influence the fluid that increases the vortex of the flow.

Figure 9 (b) shows that the higher velocity variation of the flow at $800 \mathrm{l} / \mathrm{h}$, the higher velocity, which is obtained at 1.1 $\mathrm{m} / \mathrm{s}$. Figure 9 (b) shows the characteristic of turbulence at the $R e=490$. This result means that flow on rotameter at $800 \mathrm{l} / \mathrm{h}$ still in vortex-street, which is fully turbulent.

This result can be used to estimate a characteristic of flow at a maximum capacity of rotameter at $1000 \mathrm{l} / \mathrm{h}$ or higher, where it will be more turbulence.

\section{CONCLUSION}

Fluid flow analysis using the k-epsilon model in the 3-dimensional simulation of rotameter showed a clear model of the flow that occurred. The results of theoretical analysis and numerical simulation indicate conformity. Rotameters certainly have a pattern of flow/regimes of turbulence, depending on the mass flow rate and the $R e$ number. Rotameter accuracy could be improved by reducing the turbulence regimes.

\section{RECOMMENDATION}

Results of this research can be used to optimize the floating element design of rotameter with tapered floating element model.

\section{ACKNOWLEDGMENT}

The authors wish to thank to Technical Implementation Unit for Instrumentation Development and Research Center for Electric Power and Mechatronics - Indonesian Institute of Sciences for supporting 
the research facility and permission to use ANSYS-CFX software. We would also want to extend our gratitude to Dr. Arjon Turnip, Scientist of Cogno Instrumentation for his valuable suggestions and advice at different stages of this work.

\section{REFERENCES}

Ahsan, Muhammad. 2014. "Numerical Analysis of Friction Factor for a Fully Developed Turbulent Flow Using K E $\varepsilon$ Turbulence Model with Enhanced Wall Treatment." Journal of Basic and Applied Sciences 3: 2-10. doi:2 6 9-2 77.

Alam, SA. 2008. "CFD Analysis of Fluid Flow in Rotameters."Annual Meeting on Testing and Quality.

Ángel, Marroquín-De Jesús, Olivares-Ramírez Juan Manuel, Jiménez-Sandoval Omar, Zamora-Antuñano Marco Antonio, and Encinas-Oropesa Armando. 2013. "Analysis of Flow and Heat Transfer in a Flat Solar Collector with Rectangular and Cylindrical Geometry Using CFD.” Ingeniería, Investigación Y Tecnología 14 (4). Elsevier: 553-61. doi:10.1016/ S1405-7743(13)72265-0.

ANSYS(1). 2013. ANSYS Fluent Theory Guide. 15thed. Canonsburg: SAS IP, Inc. http://www.ansys.com.

ANSYS(2). 2013. ANSYS FLUENT USER'S GUIDE. 15thed. Canonsburg: SAS IP, Inc.

Blevins, Robert D. 2001. Flow-Induced Vibration. 2nded. Florida: Krieger Publishing company.

Buckle, U, F Durst, B Howe, and A Melling. 1992. "Investigation of a Floating Element Flowmeter" 3 (4): 215-25.

Deng, Wei, Xiaoting Li, Yujiao Liang, Lide Fang, Qing He, and Yao Zhang. 2012. "The Research on Inductive Gas Rotameter Transmission System." AASRI Procedia 3: 284-90. doi:10.1016/j.aasri.2012.11.046.
Hanada, Toshihiro, Kenji Kuroda, and Koji Takahashi. 2016. "CFD Geometrical Optimization to Improve Mixing Performance of Axial Mixer" 144: 144-52. doi:10.1016/j. ces.2016.01.029.

Hosain, Md Lokman, and Rebei Bel Fdhila. 2015. "Literature Review of Accelerated CFD Simulation Methods towards Online Application." Energy Procedia 75: 3307-14. doi:10.1016/j. egypro.2015.07.714.

Husein, Zoeb, Zulkifly Abdullah, and Zainal Alimuddin. 2008. Basic Fluid Mechanics and Hydraulic Machines. Giriraj Lane: BS Publications. www. bspublications.net.

Joshi, Rakesh, S.S Jolly, and bikram jit Singh. 2013. "Effect of Float Design on the Performance of Rotameter Using Computational Fluid Mechanics." International Jurnal of Engineering and Management Research 3 (6): 15-20. doi:2250-0758.

Kulkarni, Vinayak, Niranjan Sahoo, and Sandip D Chavan. 2011. "Journal of Wind Engineering Simulation of Honeycomb - Screen Combinations for Turbulence Management in a Subsonic Wind Tunnel." Jnl. of Wind Engineering and Industrial Aerodynamics 99 (1). Elsevier: 37-45. doi:10.1016/j.jweia.2010.10.006.

Li, C W, and B Zhu. 2002. "A Sigma Coordinate 3D K - E Model for Turbulent Free Surface Flow over a Submerged Structure." Applied Mathematical Modelling 26: 1139-50. doi:10.1016/ S0307-904X(02)00081-1.

Lostedt, Per, and Per Carlbom. 1997. "Stability and Non-Normality of the K-E Equations." Journal of Computational and Applied Mathematics 83: 11-37. doi:11-37.

Mala, H K Versteg and W Malalasekera. 2007. No Title. 2nded. England: Pearson Education Limited. www. pearsoned.co.uk.

P, Pavan Kumar K, V Seshadri, and Puneeth Kumar S B. 2015. "Analysis of Flow 
Through Rotameter Using CFD." International Journal of Emerging Technology and Advanced Engineering 5 (6): 305-12.

Rolander, N, J Rambo, Y Joshi, Jk Allen, and F Mistree. 2006. "An Approach to Robust Design of Turbulent Convective Systems." Journal of Mechanical Design 128 (4): 844. doi:10.1115/1.2202882. 
Widyariset | Vol. 3 No. 1 (2017) Hlm. 9 - 18 